\title{
TEKNOLOGI PENGOLAHAN EMPING JUBIKA SEBAGAI UPAYA PENINGKATAN NILAI GUNA JAGUNG MANIS DI DESA ARJASARI KABUPATEN BANDUNG
}

\author{
Mohamad Djali, Indira Lanti Kayaputri, dan Dian Kurniati \\ Fakultas Teknologi Industri Pertanian/Universitas Padjadjaran \\ E-mail: agusdjali@unpad.ac.id
}

\begin{abstract}
ABSTRAK. DesaArjasari dikenal dengan desa yang kaya akan kekayaan alamnya. Salah satu komoditas yang diunggulkan pada kekayaan alam desa tersebut adalah jagung manis. Walaupun dekimian, pemanfaatan hasil panen jagung manis ini belum maksimal karena masih terbatas pada penjualan hasil panen pada tengkulak dan produk olahan tradisional. Oleh karenanya perlu dilakukan upaya peningkatan nilai guna dari jagung manis di Desa Arjasari, salah satunya dengan membuat produk olahan yang mempunyai nilai ekonomi lebih tinggi dan menarik untuk dipasarkan dalam bentuk emping JUBIKA (Jagung Kulit Biji kakao). Tujuan dari program pengabdian kepada masyarakat ini adalah transfer teknologi tepat guna pengolahan jagung manis menjadi produk olahan yang memiliki nilai ekonomi yang lebih tinggi sehingga dapat meningkatkan nilai guna jagung manis, memperpanjang umur simpan, dan memberikan kontribusi kepada masyarakat baik petani jagung manis maupun pengolahan makanan dalam bentuk margin ekonomi. Metode pendekatan dilakukan melalui pendekatan partisipasif dengan kegiatan survey lokasi dan potensi desa, pelatihan baik teori atau praktek, monitoring dan evaluasi, dan persiapan pemasaran. Dari kegiatan yang telah dilakukan dapat disimpulkan bahwa masyarakat desa Arjasari kecamatan Arjasari kabupaten Bandung terutama Ibu-ibu PKK, petani jagung manis, tokoh masyarakat, dan Karang Taruna menyambut baik kegiatan PPMD bertopik pembuatan JUBIKA. Pengembangan olahan berbahan baku jagung ke depan dinilai memungkinkan karena ditunjang kesediaan bahan baku jagung manis di desa tersebut. Pada kegiatan PPM tahun berikut akan dilaksanakan pengembangan untuk produk olahan singkong dan pisang yang merupakan produk khas daerah setempat.
\end{abstract}

Kata kunci: Desa Arjasari; Emping; Jagung; JUBIKA; Teknologi Tepat Guna

\section{JUBIKA EMPING PROCESSING TECHNOLOGY AS AN INCREASING VALUE FOR SWEET CORNS IN ARJASARI VILLAGE, BANDUNG DISTRICT}

\begin{abstract}
Arjasari village is known as a village that has abundant in natural wealth and one of abundant commodities is sweet corn. However, the utilization of sweet corn harvest has not run maximally yet because it is still limited to the sale of crops to middlemen and traditional processed products. Therefore, it is required an effort to improve the value of sweet corn in Arjasari village, one of them is by producing products that have higher economic and intriguing value to be marketed in the form of JUBIKA chips. The aims of this community service program are to do transfer of appropriate technology for processing of sweet corn into products that have higher economic value so as to increase the value of sweet corn, extend shelf life, and contribute to the community both sweet corn farmers and food processing in form of economic margin. The approach method was done through participatory approach such as site and potencies of the village surveys, training both in theory of production and practice, monitoring and evaluation, and marketing preparation. From the activities that have been done, it can be concluded that the village community of Arjasari, Arjasari sub-district, Bandung, especially Fostering Family Welfare, sweet corn farmers, community leader, and Karang Taruna welcomed the community service program activities in producing JUBIKA. The development of processed corn raw material was considered possible due to high availability of corn in the village. Community service program in the following year will be implemented for development of products of cassava and banana which are typical products of local area.
\end{abstract}

Key words: Arjasari Village; Chip; Corn; JUBIKA; Approriate Technology

\section{PENDAHULUAN}

Desa Arjasari dikenal dengan desa yang kaya akan kekayaan alamnya. Potensi masyarakat Desa Arjasari terdiri dari beberapa aspek yaitu pertanian, peternakan, dan kegiatan usaha produktif. Arjasari merupakan tempat yang cocok untuk mengembangkan usaha pada sektor pertanian. Desa tersebut memiliki wilayah seluas 768.848 ha, dengan ketinggian 700-1.000 di atas permukaan laut, curah hujan 3.660 per tahun, suhu harian rata-rata adalah $26^{\circ} \mathrm{C}$ (Website Resmi Desa Arjasari, 2014). Sehingga daya dukung lingkungan terhadap pertanian masih terkategori tinggi. Sektor pertanian merupakan salah satu sektor yang diunggulkan pada kekayaan alam Desa Arjasari, diantaranya adalah jagung manis sebagai salah satu yang diunggulkan pada sektor pertanian dengan produktivitas sebesar 1 - 1,5 ton per hektar. Jagung-jagung manis yang dihasilkan pada sektor pertanian Desa Arjasari kemudian dijual kepada tengkulak atau bandar seharga Rp 2.000 - Rp. 4000/kg (Website Resmi Desa Arjasari, 2014). Pemanfaatan hasil panen jagung manis ini belum maksimal, masih terbatas pada penjualan hasil panen pada tengkulak dan produk olahan tradisional seperti jagung rebus dan bakar.

Minimnya pemanfaatan dan nilai jual hasil panen jagung manis menyebabkan berkurangnya jumlah petani yang menanam jagung manis sehingga berkurangnya produksi jagung manis di daerah tersebut. Oleh karena itu, perlu dilakukannya upaya peningkatan nilai guna dari jagung manis di Desa Arjasari Kecamatan Arjasari Kabupaten Bandung. Salah satu upaya yang dapat dilakukan adalah dengan membuat produk olahan jagung 
manis yang mempunyai nilai ekonomi lebih tinggi dan menarik untuk dipasarkan sehingga memberikan margin keuntungan yang lebih besar bagi petani serta bisa menjadi produk khas daerah tersebut.

Jagung merupakan tanaman serelia yang termasuk bahan pangan penting dan menjadi bahan makanan pokok di beberapa daerah di Indonesia. Beberapa kandungan gizi yang terkandung dalam jagung dapat dilihat pada Tabel 1 .

Tabel 1. Kandungan Gizi Jagung per 100 g Bahan

\begin{tabular}{ll}
\hline \multicolumn{1}{c}{ Kandungan } & \multicolumn{1}{c}{ Jumlah } \\
\hline Kalori & $307 \mathrm{Kalori}$ \\
Protein & $7,9 \mathrm{gr}$ \\
Lemak & $3,4 \mathrm{gr}$ \\
Karbohidrat & $63,6 \mathrm{gr}$ \\
Kalsium & $9 \mathrm{mg}$ \\
Fosfor & $148 \mathrm{mg}$ \\
Ferrum & $2,1 \mathrm{mg}$ \\
Vitamin A & $440 \mathrm{SI}$ \\
Vitamin B1 & $0.33 \mathrm{mg}$ \\
Vitamin C & $12 \%$ \\
Air & $12 \mathrm{gr}$ \\
\hline
\end{tabular}

Salah satu produk olahan berbasis jagung manis adalah emping jagung yang dapat dijadikan sebagai makanan ringan atau makanan ringan. Emping jagung adalah produk olahan pangan dari bahan berpati yang digencet atau dipipihkan menjadi lempengan dengan bentuk tertentu (biasanya bulat), dikeringkan, dan digoreng renyah (Hendraswari, et al., 2015). Emping tersebut kemudian disalut dengan kulit biji kakao yang akan memberikan cita rasa coklat. Selain rasanya yang renyah dan aroma cokelat yang dihasilkan dari penyalutan kulit biji kakao, produk yang dihasilkan dapat memiliki umur simpan yang lebih lama dan diharapkan dapat meningkatkan nilai guna dari buah jagung manis. Pembentukan UKM olahan jagung manis di Desa Arjasari diharapkan dapat menjadi wadah bagi para petani jagung manis untuk dapat memproduksi dan sarana pemasaran produk olahan yang dihasilkan sehingga kegiatan dapat berlangsung secara berkelanjutan.

\section{METODE}

Metode pendekatan dilakukan melalui pendekatan partisipasif. Jenis kegiatan yang dilakukan untuk mencapai tujuan dan outcome yang diharapkan, dilaksanakan dengan metode sebagai berikut:

1. Survey awal

Survey awal dilakukan untuk menjaring informasi tentang permasalahan yang dihadapi oleh UKM Bingu untuk lebih memfokuskan bantuan yang akan disampaikan ke UKM terkait

2. Kunjungan lapangan

Melakukan kunjungan langsung ke UKM terkait untuk mengetahui kondisi yang dihadapi oleh UKM, terutama dari faktor lingkungan

3. Praktek

Melakukan praktek pembuatan produk berbahan baku jagung manis dan kulit biji kakao berdasarkan GMP

4. Pendampingan

Kegiatan pendampingan dilakukan untuk memastikan bahwa kegiatan yang dilakukan dapat dilaksanakan masyarakat secara mandiri.

5. Evaluasi

Kegiatan ini dilaksanakan untuk mengidentifikasi kemungkinan kegagalan pelaksanaan kegiatan.

6. Penyerahan bantuan alat produksi sederhana Memberikan bantuan alat produksi sederhana untuk memberikan semangat kepada msyarakat untuk terus melaksanakan proses produksi JUBIKA.

7. Persiapan pemasaran

Kegiatan ini dilakukan untuk menginisiasi produk jubika termasuk studi lapangan dan pemasarannya, serta perhitungan ekonomi secara sederhana.

\section{HASIL DAN PEMBAHASAN}

\section{Survey dan Penjajagan Potensi}

Survey lapangan dilakukan untuk melihat dan mengidentifikasi potensi desa-desa mana saja yang layak untuk dikembangkan melalui pelatihan dan alih teknologi pengolahan emping JUBIKA. Dari hasil survey yang telah dilakukan, desa Arjasari dipilih sebagai lokasi kegiatan karena merupakan sentra penanaman jagung manis di Kecamatan Arjasari. Kegiatan PPMD di Desa Arjasari ini mendapat respon yang positif dari Lurah dan Ibu-Ibu PKK di Desa Arjasari. Hal ini terlihat pada hari pertama survey awal, Lurah Desa Arjasari menyambut baik kegiatan ini mengingat potensi jagung manis di desa ini serta minat masyarakat untuk membuat olahan dan berwira usaha olahan jagung manis cukup besar.

Untuk menindaklanjuti hasil survey lapangan maka dilakukan kunjungan ke Desa Arjasari. Kegiatan dilakukan dengan wawancara terhadap pihak kecamatan untuk mendapatkan data yang valid. Pada tahap ini sekaligus dilakukan tahapan perizinan dari pihak Kecamatan Arjasari untuk melakukan kegiatan di Desa Arjasari. Pada prinsipnya pihak kecamatan sudah mengizinkan untuk dilaksanakannya kegiatan ini, sekaligus bersedia berkoordinasi untuk kegiatan selanjutnya. Hasil pertemuan disepakati bahwa pelatihan akan diikuti oleh 25 orang peserta yang terdiri dari ibu-ibu PKK, petani jagung, dan karang taruna. Pelatihan akan dilakukan di ruang musyawarah Bale Desa Arjasari.

Untuk kelancaran praktek pembuatan JUBIKA ini, disusun prosedur produksi produk ini mulai dari penyiapan jagung sampai pembuatan bahan penyalut yang terbuat dari kakao. Kegiatan ini dilakukan di Laboratorium Teknologi Pangan FTIP Unpad. 


\section{Pelaksanaan Pelatihan Teori atau Penyuluhan}

Kegiatan ini bertempat di balai Desa Arjasari kecamatan Arjasari dengan jumlah peserta sebanyak 25 orang yang terdiri dari ibu-ibu PKK dan kader/perwakilan dari setiap RW. Kegiatan dilaksanakan dalam bentuk pemaparan materi pelatihan oleh tim PPMD meliputi: (a). Teknologi Pengolahan Jagung, (b). Pengetahuan mengenai GMP (Good Manufacturing Practice) dan Sanitasi, serta (c). Teknologi Pengemasan Produk Pangan. Dengan adanya penyuluhan materi tersebut diharapkan masyarakat setempat dapat lebih meningkat kepeduliannya dalam hal penyajian makanan dan tingkat keamanannya.

Pada akhir kegiatan dilakukan pembagian doorprize dengan memberikan pertanyaan seputar materi pelatihan untuk memotivasi peserta dalam memahami materi. Pada pertemuan tersebut juga telah dikoordinasikan mengenai kegiatan selanjutnya yaitu pelaksanaan praktek pembuatan emping JUBIKA dan dijadwalkan pada minggu pertama.

\section{Pelatihan Pembuatan Emping JUBIKA}

Kegiatan bertempat di balai Desa Arjasari dan dihadiri oleh 25 perserta yang terdiri dari ibu-ibu PKK dan kader/perwakilan dari setiap RW. Kegiatan diawali oleh pemberian materi mengenai prosedur pembuatan emping JUBIKA dan dilanjutkan dengan praktek pembuatan produk. Pembuatan emping JUBIKA dilaksanakan oleh Tim PPMD bersama ibu-ibu PKK desa Arjasari dan dibantu oleh dua orang mahasiswa. Pembuatan produk diawali dengan perebusan dan pemipihan jagung, pengeringan dan penggorengan emping jagung (Antarlina dan Krismawati, 2011). Tahapan terakhir dari produksi JUBIKA adalah pembuatan formulasi coklat penyalut emping.

Setelah melakukan praktek pembuatan emping JUBIKA oleh Tim PPMD, ibu-ibu PKK diminta untuk melakukan uji coba produksi emping JUBIKA dengan menggunakan jagung hasil panen desa Arjasari. Pembuatan emping jagung berbahan baku jagung khas desa Arjasari diwakili oleh ketua PKK dan timnya dan hasilnya akan dipantau dan dievaluasi pada pertemuan selanjutnya. Pemantauan dan evaluasi bertujuan untuk melihat prospek produksi emping JUBIKA dan kendalakendala yang dihadapi selama proses produksi. Kegiatan ini juga diikuti dengan pemberian bantuan alat produksi sederhana untuk digunakan oleh ibu-ibu PKK dalam memproduksi emping JUBIKA serta diakhiri dengan pembagian doorprize mengenai materi pelatihan minggu sebelumnya.

\section{Pemantauan dan Evaluasi Produksi Emping JUBIKA}

dilaksanakan pemantauan dan evaluasi oleh tim PPMD terhadap proses produksi emping JUBIKA oleh ibu-ibu PKK desa Arjasari. Kegiatan ini bertujuan untuk melihat pencapaian dari kegiatan-kegiatan yang telah dilaksanakan sebelumnya. Hasil evaluasi digunakan sebagai bahan dan acuan untuk merancang kegiatan
PPMD pada tahun berikutnya. Kegiatan dihadiri oleh tim PPMD dan perwakilan dari PKK bertempat di balai Desa Arjasari. Kegiatan tersebut berisi diskusi mengenai kendala-kendala yang dihadapi selama proses produksi. Terdapat beberapa hambatan yang dihadapi yaitu pertama produksi emping JUBIKA yang memakan waktu lama sekitar kurang lebih dua hari, peralatan produksi yang masih sederhana sehingga menyulitkan pada proses produksi emping, dan imbangan penyalut coklat yang masih perlu disempurnakan.

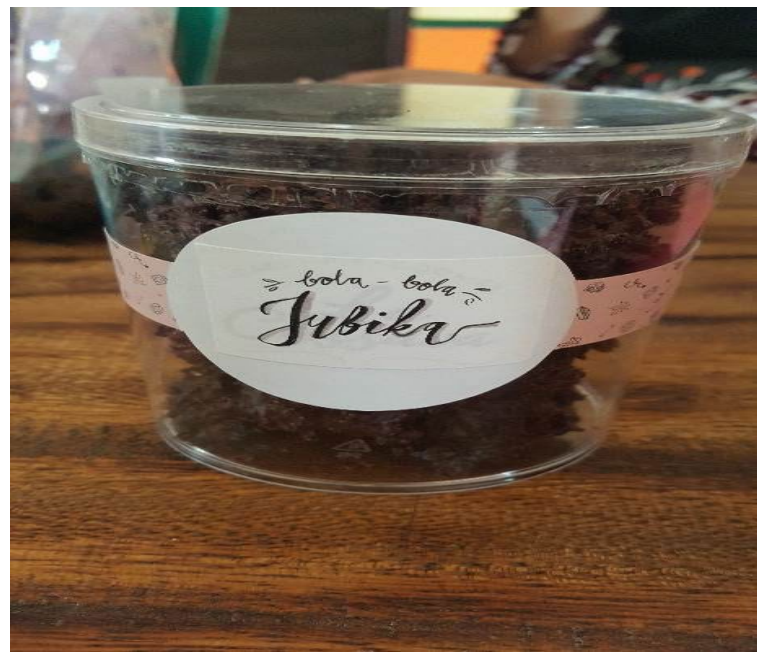

(Dokumentasi Pribadi)

Gambar 1. Produk JUBIKA hasil produksi Ibu-Ibu PKK desa Arjasari

\section{Pengembangan Strategi Pemasaran dan Penguatan Kelembagaan}

Pengembangan strategi pemasaran belum dilaksanakan karena terkendala masalah :

a. Produksi

Proses produksi masih belum optimal karena selama ini dirasakan produk jagung belum memiliki harga jual yang baik, dimana jagung hanya dijual mentah dan diolah sederhana

b. Aktifitas Ibu - ibu PKK

Kesibukan Ibu - ibu PKK menyebabkan kegiatan produksi menjadi terhambat dan menjadi tidak fokus. Hal ini berpengaruh terhadap kualitas produk yang dihasilkan

c. Target pasar

Target pasar yang belum jelas sehingga penduduk setempat memiliki rasa ragu dalam melaksanakan pengembangan UKM Olahan Jagung ini.

d. Penguatan kelembagaan

Kegiatan produksi belum berjalan dengan rutin dan masih bersifat insidental sehingga dirasakan perlunya lembaga khusus yang bergerak di bidang olahan pangan di Desa Arjasari. Yang bertindak sebagai koordinator kegiatan yaitu Ibu - ibu PKK Desa Arjasari dan diharapakan ke depan dapat dikembangkan suatu UKM yang dipimpin oleh PKK Desa Arjasari, khususnya UKM Olahan Jagung. 


\section{SIMPULAN}

Program PKM ini telah berhasil dilaksanakan di Desa Arjasari Kecamatan Arjasari Kabupaten Bandung. Kegiatan berupa transfer teknologi pengolahan jagung manis menjadi produk dengan nama JUBIKA (Jagung Kulit Biji Kakao). Produk JUBIKA dapat meningkatkan nilai jual jagung menjadi lebih tinggi dibandingkan dengan nilai jual jagung manis itu sendiri. Masa penyimpanan produk atau umur simpan produk juga menjadi lebih lama karena adanya sentuhan teknologi tepat guna. PKM ini diharapkan dapat memberikan kontribusi kepada masyarakat Desa Arjasari baik petani jagung maupun produsen makanan olahan dalam bentuk margin ekonomi.

\section{UCAPAN TERIMAKASIH}

Program Hibah PPMD Multi Tahun 2017 Universitas Padjadjaran
DAFTAR PUSTAKA

Arianingrum, R. 2004. Kandungan Kimia Jagung Dan Manfaatnya Bagi Kesehatan. Budidaya Pertanian. 1: $128-130$.

Antarlina, S.S. dan Krismawati, A. 2011. Pengkajian Pembuatan Emping Jagung dari Tiga Varietas dengan Dua Teknik Pembuatan. Prosiding Seminar Nasional Serelia. Jakarta. p. 530-538.

Hendraswari, E., Sutardi, dan Santoso, U. 2015 Pengaruh pengeringan terhadap Sifat Fisik, Kimia dan Organoleptik Emping jagung Kuning. Skripsi. Teknologi Hasil Pertanian Universitas Gadjah Mada, Jogyakarta.

Website Resmi Desa Arjasari. 2014. Potensi Desa Arjasari. http:arjasari-bandung.desa.id/uncategorized/ potensi-desa/.

Website Resmi Desa Arjasari. 2014. Sumber Daya Alam Desa Arjasari. http:arjasari-bandung.desa.id/ uncategorized/sumber-daya-alam/. 